\title{
"We are Proud to be a Leading Company with Global Reach and Worldwide Impact": Positively Evaluative Lexis in the Language of Recruitment Advertising
} „Didžiuojamės, kad esame pirmaujanti, visuotinai pripažinta ir pasaulinę įtaką turinti įmonè": teigiamai konotuota jdarbinimo reklamos leksika

\section{SOCIOLINGUISTICS / SOCIOLINGVISTIKA}

\section{Pavel Reich}

Department of Language and Cultural Studies, Faculty of Regional Development and International Studies, Mendel University in Brno, Czech Republic

$\Gamma$ Crossef http://dx.doi.org/10.5755/j01.sal.0.33.20081

Companies' positive self-presentation has become an essential part of job advertising and helps employers attract potential applicants for the vacancies they are offering. This paper focuses on the various forms of positively evaluative lexis that appear in the company profiles cited on the employment website Monster.com. Evaluative or loaded words can be defined as words that evaluate reality either in a positive or a negative way, thus evoking in people a positive or a negative attitude towards a particular subject, in this case, the potential employer.

The analysis is both qualitative and quantitative and is based on the three-pronged approach, i.e., the combination of manual analysis of individual texts, small-scale corpus analysis and large-scale corpus analysis. It is based primarily on appraisal theory, focusing predominantly on the category of ATTITUDE expressed in the vocabulary used. However, the analysis showed that the persuasive techniques of employers trying to attract applicants are rather complex and it has proved necessary to take into account notions from other theories, namely orientational metaphor and the concept of the so-called purr words, i.e., words the conceptual meaning of which is backgrounded by its positive connotations. This concept has recently been developed mostly under the name of Schlagwort within the field of Politolinguistik in Germany, but, as the analysis shows, can usefully be transferred from political discourse to corporate discourse, including the discourse of recruitment.

KEYWORDS: recruitment advertising, appraisal, attitude, purr word, orientational metaphor, semantic prosody.

\section{$\underset{1922}{\mathrm{ktU}}$}

Research Journal Studies about Languages No. $33 / 2018$ ISSN 1648-2824 (print) ISSN 2029-7203 (online) pp. 43-56

DOI 10.5755/j01.sal.33.0.20081 
The subject of this study is the language of recruitment advertising. Nowadays, companies that want to hire the best applicants must know how to sell themselves and how to show that they are a better employer than others, not only from the point of view of the relationship between the employer and the employee, but also in terms of the relation of the employer and society. This aspect is emphasized, e.g., by Łącka-Badura, who claims that one of the main objectives of recruitment advertising is the projection of a positive image of the employing organization (2015, p. 5). Similarly, Rafaeli sees the primary purpose of recruitment advertisements not to recruit employees, but rather as a "means of helping individuals in the job market learn about available employment relationships and make a choice among these alternatives" (2001, p. 248). This paper focuses on the linguistic strategies that are used for such a purpose. Most such strategies are well-known for being commonly used in the language of politics, and this paper is thus to a high degree inspired by the analyses of political language. It attempts to demonstrate that these strategies can also be found in the language of business, and in this case, in the language of human resources.

The aim of this research is to identify the most frequent positively evaluative expressions in the language of recruitment advertising and to demonstrate how and in what contexts such expressions are used as a persuasive tool in companies' attempt to make the best impression possible and to attract the potential candidates to apply for a job with them.

The understanding of evaluation in this article corresponds to the definition of this concept by Hunston and Thompson (1999, p. 5). They see it as "the broad cover term for the expression of the speaker or writer's attitude or stance towards, viewpoint on, or feelings about the entities or propositions that he or she is talking about" (Hunston and Thompson, 1999, p. 5). It is a concept situated on the borderline between two linguistic sub-disciplines - semantics and pragmatics. From the semantic point of view, evaluation is more or less synonymous with connotation. It is words that have positive or negative connotations embedded in themselves. From the pragmatic point of view, it is understood rather as the attitude of the language user towards the word who perceives it as positive or negative. The two different perspectives are accentuated by Leech (1990), who distinguishes between connotative meaning and affective meaning, the first relating to the real-world experience that people associate with the word and the latter relating to the speaker's personal feelings. Both connotative and affective meanings are unified by Leech with other three meanings (social, reflective and collocative) under the heading of associative meaning and are put into opposition with conceptual meaning (Leech, 1990). Thus, from the semantic point of view, positive or negative evaluation equals positive or negative associative meaning.

Another very important distinction between conceptual and associative meaning, according to Leech, is that associative meaning is less stable than conceptual meaning. While conceptual meaning is shared by users of the same language, associative meaning varies with each individual's experience (Leech, 1990, p. 43). This may lead to situations when the associative meaning of words is used for conveying attitudes and emotions. Leech (1990, p. 43) mentions two such situations: 1) as associative meaning varies from one person to another, its use can cause miscommunication or misunderstanding, and 2) readers/listeners may be misled by associative meaning (in this case particularly, affective meaning) which is predominant over conceptual meaning, and as a result they are not able to appraise the information properly. Leech (1990, p. 43) claims that the second situation may be dangerous as it can be misused in order to influence people's opinions and perception of reality, and favourable or unfavourable words can thus be chosen in order to manipulate people's view on certain things or issues. 
The concept of evaluation has recently also been dealt with within the framework of the systemic functional grammar, which "is concerned with what speakers are doing when they use language and why on particular occasions of use they formulate their utterances in the way they do" (Hart, 2014, p. 20). Of the three functions of language - ideational, interpersonal and textual - suggested by Halliday and Matthiessen (2004), evaluation is closely connected to the interpersonal function of language through which the speaker "intrudes himself into the context of situation, both expressing his own attitudes and judgements and seeking to influence the attitudes and behaviour of others" (Halliday, 2007, p. 184). This interpersonal function can be considered as belonging to the sphere of pragmatics (Leech, 1983, p. 56).

Halliday's notions are elaborated on in particular within the appraisal theory. Appraisal encompasses three different subsystems - ATTITUDE, ENGAGEMENT and GRADUATION. It is the subsystem of ATTITUDE through which the speaker or writer expresses his or her opinion through evaluative lexis.

Appraisal is defined by White (2015) as "all evaluative uses of language, including those by which speakers/writers adopt particular value positions or stances and by which they negotiate these stances with either actual or potential respondents". Martin and White (2005) distinguish between three different systems through which appraisal can be realized in lexicogrammar. They are ATTITUDE, ENGAGEMENT and GRADUATION.

ATTITUDE encompasses expressions expressing the positive or negative attitude of the speaker to the matter. This system is the only relevant to the present analysis and is discussed in more detail below. ENGAGEMENT is a cover term for expressions expressing the speaker's position on the content of the message. It is realized mostly through modal verbs (e.g., may, might, could), adverbs (e.g., possibly, probably, definitely) or verbs (e.g., believe, suggest, be convinced, etc.). The purpose of the third system, GRADUATION, is to amplify or weaken the content of the message. It is realized, for example, by some adverbs, such as really happy, deeply regret, hyper-efficient, etc.

As stated above, the only system relevant to the present analysis is ATTITUDE. It can be further divided into three subsystems: AFFECT, JUDGEMENT and APPRECIATION. The first one, AFFECT, is defined as "a semantic resource for construing emotions" (Martin, 1999, p. 148). Evaluation based on the positive or negative emotions of the speaker is conveyed by some verbs (e.g., to love/to hate, to frighten/to reassure, to interest/to bore), some adverbs (e.g., happily/sadly), some adjectives (e.g., happy/sad, worried/confident, angry/pleased) or some nouns (e.g., joy/despair, confidence/insecurity). The second subsystem, JUDGEMENT, can be understood as "the institutionalization of feeling, in the context of proposals (norms about how people should and shouldn't behave)" (Martin, 1999, p. 155). Similarly to the previous subsystem, the judgements about behaviour can be positive or negative and are usually expressed by adjectives such as right, wrong, ethical, responsible, innocent, cruel, brutal, or by nouns created from these adjectives by way of nominalization (e.g., responsibility, cruelty, brutality, etc.). The last subsystem, APPRECIATION, is defined by Martin and White (2005, p. 56) as "meanings construing our evaluations of 'things', especially things we make and performances we give, but also including natural phenomena - what such things are worth (how we value them)". APPRECIATION is typically indicated by the use of some adjectives, such as beautiful, unattractive, yummy, simple, etc.

The subdivision of the system of ATTITUDE can thus be summarized as follows:

_ AFFECT (emotions; reacting to behaviour, text/process, phenomena);

_ JUDGEMENT (ethics; evaluating behaviour);

APPRECIATION (aesthetics; evaluating text/process, natural phenomena).

\section{Appraisal Theory}


Semantic Prosody

Loaded Language and Purr Words
In addition to the above-described straightforward attitudinal meanings of lexical items themselves, a special case of hidden or implied evaluative meaning has been suggested by various scholars. The idea is that "if a lexical item most frequently occurs in a context of clearly positive or negative attitudinal meaning, then when it occurs in a different context that positive or negative meaning will colour the interpretation of the given instance. The result is that an additional attitudinal meaning, derived intertextually, is implied" (Hunston, 2007, p. 250). Explained simply in semantic terms, a seemingly neutral word that commonly collocates with positively or negatively evaluative words can itself carry implied positive or negative meanings and connotations. Large corpora, in the case of English either the British National Corpus (BNC) for British English or the Corpus of Contemporary American English (COCA) for American English, are employed for the identification of such recurring collocates.

The well-established term for this notion is semantic prosody and despite its name, it is agreed that it is attitudinal and on the pragmatic side of the semantics/pragmatics continuum (Sinclair, 2004, p. 34). The interrelation between the above-described appraisal system (and its subcategories of AFFECT, JUDGEMENT and APPRECIATION) and semantic prosody is suggested by Stewart (2010). Thus, even though the concept of semantic prosody has been widely criticised, I do consider it useful for the analysis of evaluative lexis in the present study, not as a source of positive evaluation itself, but rather as a supportive aspect. In other words, I suggest that the positive attitudinal meaning of a lexical item can be enhanced by its positive semantic prosody. I understand semantic prosody in this context as an analogue of what Bolinger (1980) calls hidden bias (i.e., subjective positive or negative connotation words might evoke in language users), the only difference being the fact that whereas the identification of hidden bias is rather tentative and subjective, semantic prosody can be stated objectively by analysing large corpora.

It follows from what has been stated above that words with strong positive or negative attitudinal meaning can be considered biased or loaded. Bolinger (1980) puts loaded or biased language into contrast with propositional language, which, according to him, is the language used for stating facts; it is the language of responsibility and is truthful and accurate (1980, pp. 69-70). Loaded language, on the other hand, is described by Bolinger as the language the objective of which is to put something in either a favourable or unfavourable way.

A special type of loaded words, discussed in particular by Leech (1990, pp. 43-44), is expressions in which the associative meaning is so strong that the conceptual meaning very often seems to be almost irrelevant. Hayakawa (1949) calls such negative expressions snarl words (e.g., fascism and communism) and positive expressions purr words (e.g., freedom and democracy). Purr words, which are an essential notion for the present analysis, could comprehensibly be defined as words with the purpose to induce a positive response or association in the person who reads them or hears them. Typically, they are used to appeal to people's emotions rather than their reasoning, and thereby get them on the speaker's or reader's side.

The same concept, called meaningless words, is discussed by Orwell in his essay Politics and the English Language (1946). He criticizes the frequent use of this type of language in the field of politics:

The word Fascism has now no meaning except in so far as it signifies 'something not desirable'. The words 'democracy', 'socialism', 'freedom', 'patriotic', 'realistic', 'justice', have each of them several meanings which cannot be reconciled with one another. In the case of a word like 'democracy', not only is there no agreed definition, but the attempt to make 
one is resisted from all sides. It is almost universally felt that when we call a country democratic we are praising it: consequently, the defenders of every kind of regime claim that it is a democracy, and fear that they might have to stop using the word if it were tied down to any one meaning. Words of this kind are often used in a consciously dishonest way. That is, the person who uses them has his own private definition but allows his hearer to think he means something quite different (Orwell, 1946, pp. 212-213).

This topic has been extensively studied in the last decades in particular in Germany within the field of Politolinguistik under the term Schlagwort. The German equivalent of purr word is positives Schlagwort, which is further divided into three categories - Fahnenwort (e.g., solidarity), Hochwertwort (e.g., democracy) and anderes positives Schlagwort (e.g., environmental protection). The German equivalent of snarl word is Stigmawort (for details see Klein, 2014; Niehr, 2014).

Even though the concept of purr and snarl words has been mostly discussed within the domain of politics, which is also the case of both Orwell and the German tradition, it can safely and usefully be transferred to the domain of business and corporate language. Just like politicians try to influence and sometimes even manipulate the public's opinions on certain issues and loaded language can be very useful for them, businessmen try to influence or manipulate their clients, managers their subordinates, etc. Gingell (2015) attempts to find parallels between the misused language of politics criticized by Orwell and contemporary language of human resources by paraphrasing Orwell's criticism of the euphemistic expressions common in post-war politics as follows:

Defenceless villages are bombarded from the air, the inhabitants driven out into the countryside, the cattle machine-gunned, the huts set on fire with incendiary bullets: this is called pacification. Millions of peasants are robbed of their farms and sent trudging along the roads with no more than they can carry: this is called transfer of population or rectification of frontiers. People are imprisoned for years without trial or shot in the back of the neck or sent to die of scurvy in Arctic lumber camps: this is called elimination of unreliable elements. Such phraseology is needed if one wants to name things without calling up mental pictures of them (Orwell, 1946, pp. 217-218).

Yes, HR is not explaining away murders, but they nonetheless deliberately misuse language as a sort of low-tech mind control to avert our eyes from office atrocities and keep us fixed on our inboxes. Thus, mass sackings are wrapped up in cowardly sophistry and called rightsizings, individuals are offboarded to the jobcentre and the few hardy souls left are consoled by their membership of a more streamlined organisation (Gingell, 2015).

The transferability of the above-described theories from political language to corporate language thus definitely is worth further investigation, and this paper attempts to contribute to this undertaking.

The last way to make something sound positive is by the use of orientational metaphor, which is a specific type of conceptual metaphor. A clear definition is given by Kövecses (2010, p. 328) who describes it as a metaphor that "enables speakers to make a set of target concepts coherent by means of some basic human spatial orientations, such as up-down, in-out, centre-periphery, and the like". Typical examples of orientational metaphor include HAPPY IS UP - SAD IS DOWN; FORESEEABLE FUTURE EVENTS ARE UP (AND AHEAD); HIGH STATUS IS UP - LOW STATUS IS DOWN; GOOD IS UP - BAD IS DOWN. This can be demonstrated by example sentences,

\section{Orientational Metaphor}


Methodology and Corpus such as He's at the bottom of the social hierarchy; She fell in status; We hit a peak last year, but it's been downhill ever since.

In each case, one of the opposite directions tends to be positive and the other one negative. Kövecses (2010, p. 40) gives a list of typical common bipolar or bivalent spatial image schemas. The ones perceived as positive are whole, centre, link, balance, in, goal, and front, whereas their opposites, not whole, periphery, no link, imbalance, out, no goal, and back, are commonly considered to be rather negative.

It is important to bear in mind, however, that such a type of metaphorical orientations is not arbitrary. It is deeply embedded in human physical and cultural experience. A typical example is the perception of the future. In some cultures, it is in front of us, while in other cultures it is behind us (Lakoff and Johnson, 1980, p. 14). As the present analysis deals with texts published in the United States of America, it only takes into consideration the Euro-Atlantic cultural tradition.

The research is both quantitative and qualitative and is based on the three-pronged framework to discourse analysis as suggested and described by Bednarek (2009). This approach involves a) manual analysis of individual texts gathered by the author, b) semi-automated smallscale corpus analysis of these texts, and c) large-scale computerized corpus analysis carried out using large corpora such as BNC or COCA (Bednarek, 2009, p. 19). The main benefit of this "triangulation" of discourse analysis is seen predominantly in its complexity, each of the prongs providing a different insight and perspective, thus improving the validity of the research findings.

My corpus is composed of company profiles cited on the employment website Monster. com, in particular the profiles included in the " 50 companies with impressive diversity hiring records" section and in the "Monster 100 companies hiring in June 2017" section. The former is a list of 50 companies that was compiled by measuring American top 1,000 publicly traded companies against the number of ethnic minority groups represented in its employee base, senior management and board of directors as well as the percentage of total procurement dollars spent on diversity practices. The latter is simply a list of the companies with most vacancies offered on Monster.com in the particular month. These include companies hiring in health care, transportation, hospitality, as well as many other sectors.

After putting together the company profiles from these two sections, a corpus of approximately 10,000 words was compiled. The corpus is not extensive, but it has proved sufficient for the purposes of this study, i.e., to bring into focus the tendencies occurring in recruitment advertising in terms of evaluative language.

First, individual text analysis was carried out focusing on evaluative (or in Bolinger's words loaded) lexis as described above. Items that showed signs of positive evaluation were selected, taking into consideration the context in which they were being used. This manual analysis was subsequently elaborated on by a small-scale corpus analysis for which the corpus manager Sketch Engine was used, enabling to quantify the previously identified data. Lastly, a large-scale corpus analysis was carried out, in particular in order to identify the semantic prosody of the lexical items analysed. As Monster.com is primarily an Americanbased employment website and the company profiles analyzed were American, the Corpus of Contemporary American English (COCA) was used for this purpose. It is the largest freelyavailable corpus of English and contains more than 560 million words of text.

When seeking the connotations of adjectives and nouns in this corpus, the aim was to find out which other adjectives these words occur with, as the collocating adjectives express the quality which is typical of the adjective or noun and often appear along with it. 
As far as adjectives are concerned, relevant collocates are considered adjectives which occur within the span of two words to the left or two words to the right of the keyword. In the case of nouns, only one qualifying adjective preceding the noun is taken into consideration. The collocates are subsequently selected in dependence on the context. For example, the most frequent collocating adjectives of the word dictator are Iraqi, brutal, military, communist, Soviet, late, and ruthless. It can be observed that the collocates that can be considered as relevant in this case, i.e., have a strong positive or negative attitudinal meaning, are the adjectives brutal and ruthless.

A somewhat different method has to be employed for the identification of attitudinal meanings or loadedness of verbs. Most evaluative verbs designate actions which are automatically viewed as positive or negative (e.g., win $\mathrm{x}$ lose, build $\mathrm{x}$ destroy, etc.). The loadedness thus does not consist of positive or negative connotations, but rather of the speaker's description of a fact as good or bad without giving the listener the option to decide about the goodness or badness himself/herself (Bolinger, 1980, p. 80). It is thus necessary to identify the positivenegative pair of verbs by finding the opposite meaning of the used verb, i.e., its antonym. These were taken from the Oxford Dictionary of Synonyms and Antonyms (2007).

In the following analysis, evaluative lexis was categorised into five groups. The first three are based on the appraisal theory and they are the three subsystems of the system of ATTITUDE AFFECT, JUDGEMENT and APPRECIATION. As it is demonstrated in the analysis, the positive evaluativeness of some of the expressions belonging to these three groups is enhanced either by their semantic prosody or by the fact that the expression is an orientational metaphor. The fourth group is purr words as defined above, and the last group is words or short phrases that can be considered as orientational metaphors.

AFFECT manifests itself in the words denoting togetherness (see Table 1). The most frequent manifestations are the words team and family.

\begin{tabular}{l|c|l} 
& Frequency & \multicolumn{1}{c}{ Semantic prosody } \\
\hline team & 22 & good, new, best, great, all-star, winning \\
\hline family & 21 & large, close, immediate, nuclear, happy \\
\hline together & 8 & \\
\hline connect + connection & 6 & \\
\hline integrate & 4 & \\
\hline collaborate + collaborative & 4 & \\
\hline
\end{tabular}

\section{Results}

Affect

Table 1

Togetherness

Team collocates nine times with the possessive pronoun our and in six cases the context is joining a team. As demonstrated in the following two examples, the word is often surrounded by other positively evaluative lexical items (mostly of the category of JUDGEMENT), in combination with which it forms a string of expressions whose purpose is to persuade the reader about the professionalism of the current staff and future colleagues of the potential applicant.

(1) Our dedicated team is the group of certified experts many of which have years of experience in their related field of expertise.

(2) You'll join a team of experts in aerospace, electronics, information systems, and technical services. 
The way the word family is used in the corpus is a trickier one. It is used in a number of different contexts, but always with the intention to please the reader. The three following contexts are the most frequent. First, the company description claims that it is family-owned, which, in particular in the American context, is supposedly perceived as something positive. Second, the word is used metaphorically in the sense that being the staff of the company in question is like being a family. Third, the meaning of the word family is synonymous with customers or clients; evidently in order to evoke affective feelings.

(3) We are proud to be family owned and we welcome each new team member as part of the family.

(4) At National Income Life Insurance Company, we treat each of our sales professionals like family.

(5) We offer complete custom home comfort services specifically designed for you and your family...

The positiveness of both team and family is enhanced by their positive semantic prosodies, as shown in Table 1 above.

The other most frequent words belonging to the category of AFFECT are together, connect/ connection, integrate and collaborate/collaborative. In most cases, they are all used when speaking about people, about being better when doing things together, making connections with others, being a highly integrated network, and having collaborative teammates; all that to the benefit of the workers, the company itself, but often also to the global well-being. It is interesting to notice that sentences in which these expressions are used tend to become strings of such empty positive words, as can be seen in the following examples:

(6) Empowering careers and commerce around the globe takes more than innovative thinkers, collaborative teammates and incredible technology. It calls on the values, purpose and mission that have driven us right from the start.

(7) Raymour \& Flanigan is a family-owned, established furniture company that believes our people are our greatest asset and that if we work together anything is possible.

Judgement

\begin{tabular}{ll|c} 
Table 2 & & Frequency \\
$\begin{array}{c}\text { Expertise and } \\
\text { professionalism }\end{array}$ & help & 27 \\
\cline { 2 - 3 } & talent + talented & 18 \\
\cline { 2 - 3 } & committed & 16 \\
\cline { 2 - 3 } & expert & 9 \\
\cline { 2 - 3 } & dedicated & 9 \\
\hline
\end{tabular}

By far the most frequent expression belonging to this category is the verb help. Those that are helped are either the company's customers or staff.

(8) What makes Cognizant unique is our ability to help clients meet both challenges. We help them enhance productivity by ensuring that vital business functions work faster, cheaper and better.

The subject of the help is always thoroughly positive, but at the same time extremely vague. The word help itself is rather vague, too. As stated above, positive evaluation in verbs stands out when put into opposition with its antonym, in this case, the words hinder, impede, worsen. 
It can thus be understood that by promising help the employer does not make any substantial commitment; the meaning of help clearly implies that effort must be made primarily by those who are helped.

The other four expressions in this category - talent/talented, committed, expert and dedicated - are all used in a similar way and in similar contexts. All of them apply either to the employees of the company or the potential applicants.

(9) Our dedicated team is the group of certified experts many of which have years of experience in their related field of expertise.

The category of APPRECIATION is represented in the corpus by two thematic groups. The first theme is innovation and improvement and the second theme is being successful and ahead of others.

\begin{tabular}{l|c|l|c} 
& Frequency & Semantic prosody & $\begin{array}{c}\text { Orientational } \\
\text { metaphor }\end{array}$ \\
\hline grow + growth + growing & 38 & & $\sqrt{ }$ \\
\hline innovative + innovation + innovator & 30 & creative, exciting, unique, bold & \\
\hline new & 21 & & \\
\hline develop + development & 16 & & \\
\hline improve + improving & 14 & & \\
\hline build & 13 & & $\sqrt{ }$ \\
\hline
\end{tabular}

Table 3

Innovation and improvement

Within the first thematic group, as demonstrated in Table 3, the most frequent expression is grow, which appears in the studied corpus as a verb, a noun or an adjective. It is either the company and its employees that grow, the company will help you grow, or the number of the company's customers grows. The positiveness of the word grow is enhanced by the fact that it is an orientational metaphor of the type GOOD IS UP - BAD IS DOWN. Thus, the higher something grows, the better it is. Similarly, the word build, which appears in the corpus 13 times, is a representative of the same orientational metaphor, the only difference being in the agent of the action. The use of the word build implies that the action is performed by somebody else.

The second most frequent word - innovative and its variants innovation and innovator - and the third most frequent word - new - have a lot in common, since they are more or less synonymous. As it can be seen from Table 3 above, the most frequent relevant collocates imply that when something or someone is innovative, it/he/she is also creative, exciting, unique and bold. The positive evaluativeness of the word is thus supported by its positive semantic prosody.

(10) Our unique industry-based, consultative approach helps clients envision, build and run more innovative and efficient businesses.

The expressions develop and development appear in the corpus in many different contexts, the most frequent being personal development, career development and professional development.

The word improve can also be found in various contexts, such as improve productivity or improve experience. The most frequent and most interesting, however, is the use of the collocations improve somebody's life or quality of life. 
Table 4 Being successful and ahead of others

\section{Purr Words}

\author{
Table 5 \\ Abstract catchwords
}

(11) Bosch improves quality of life worldwide with products and services that are innovative and spark enthusiasm.

(12) We have modest goals: Improve the lives of others. Change the landscape of health care forever. Leave the world a better place than we found it.

The second group of words that belong to the APPRECIATION category is entitled being successful and ahead of others. The most frequent expressions of this category identified in the corpus are listed in Table 4 below.

\begin{tabular}{l|c|c} 
& Frequency & $\begin{array}{c}\text { Orientational } \\
\text { metaphor }\end{array}$ \\
\hline lead + leader & $\mathbf{4 0}$ & $\sqrt{ }$ \\
\hline best & 25 & \\
\hline unique & 15 & \\
\hline top & 14 & $\sqrt{ }$ \\
\hline strength + strong & 11 & \\
\hline successful + succeed & 10 & \\
\hline
\end{tabular}

Similarly to the previous thematic group, the positive evaluativeness of the most frequent word lead/leader is also enhanced by the fact that it is also an orientational metaphor, in this case of the type FRONT IS GOOD - BACK IS BAD. Of the 64 analyzed company profiles, 40 claim that the company described is a leader (in most cases in its field or in innovation) or a leading provider of a particular kind of services or goods.

Another orientational metaphor that was identified in this category was represented by the adjective top, which appears in the corpus 14 times. Similarly to the above-mentioned verbs grow and build, it implies that GOOD IS UP - BAD IS DOWN. The second most frequent expression in this category is the superlative best, which is used synonymously with top, but lacks the orientational positive aspect of the word top. The remaining three expressions unique, strong and successful, together with their variants strength and succeed, are used in a similar way, describing the company in question, with the above-described purpose to project a positive image of the employing organization. It is worth noticing that some of the appreciative expressions listed here are used together in one sentence (see Examples 10 and 13), this accumulation enhancing the positive impression to the detriment of the content. In such cases, we can claim that the language corresponds to the definition of doublespeak, i.e., deliberately obscure language (see Lutz, 1990; Lutz, 1996).

(13) The basis for the company's future growth is its innovative strength.

The expressions that are listed in Table 5 below commonly appear in the studied corpus and can be considered as purr words, because they correspond to the definition stated above. All of them are abstract expressions with rather vague conceptual meanings, and each language user might visualize different things when hearing or reading them. In all cases, however, it is very likely that when speaking about values, visions, future, goals or dreams, their visualizations will be positive and optimistic. It is the category of purr words in which the most frequent positive collocates matter the most when explaining the positive loadedness of these words themselves.

\begin{tabular}{l|c|l} 
& Frequency & Semantic prosody \\
\hline value & 21 & high, great, total, real, best \\
\hline vision & $\mathbf{1 7}$ & low, peripheral, new, clear \\
\hline future & 13 & near, foreseeable, better, bright \\
\hline mission & 13 & new, primary, military, important \\
\hline goal & 11 & ultimate, primary, main, common \\
\hline dream & 6 & American, bad, lifelong, impossible, new, big \\
\hline challenge & 6 & biggest, real, big, major, greatest \\
\hline
\end{tabular}


Mission, vision and value statements are important concepts in management. However, from the linguistic point of view, these three have become empty words, similar to the word democracy criticized by Orwell (see above). Not even the contexts in which these words are used in the corpus give us a hint what exactly is meant by them. It is implied that the companies' values, visions, missions, etc. are worth identifying with, but they are rarely stated explicitly. In most cases, the reader can only guess and is free to come up with his or her understanding of their exact meaning.

(14) We seek to attract the very best candidates, those who will model our values and embrace our mission and vision.

(15) It calls on the values, purpose and mission that have driven us right from the start.

(16) So if you're excited by the idea of making a real impact, a career with Apple might be your dream job. Just be ready to dream big.

In addition to the above-described four words that can be considered as orientational metaphors (grow, build, lead and top), there is a group of words that are all related to the positive perception of globalism in the contemporary business world (see Table 6).

A substantial number of companies tend to present themselves as being global and having an impact on the whole world. Some of them also put emphasis on the fact that they are expanding to other parts of the world.

(17) From our early roots as a Seattle,

\begin{tabular}{l|c} 
& Frequency \\
\hline world & 36 \\
\hline worldwide & 12 \\
\hline global & 34 \\
\hline expand & 8 \\
\hline globe & 6
\end{tabular}
Washington bike-messenger company to our present day, multi-billion-dollar global corporation, our team has held a singular focus - empowering commerce around the world.

(18) We also plan to expand into Latin America with our acquisition of lusacell - Mexico's leading wireless company.

All these expressions are orientational metaphors of the category WHOLE IS GOOD - NOT WHOLE IS BAD. The word world, however, is a tricky one, as it is used in many different contexts and not always meaning the world as such, for example in the following sentence:

(19) We encourage you to take risks and in return, offer a world of rewards and benefits for performance.

Notwithstanding, even in a case like this, the word is used for the purpose of giving a positive impression and the orientational metaphor explanation of the word's positiveness is still valid.

Table 7 offers the second group of orientational metaphors, which differ from all the preceding examples of positively evaluative lexis. They are phrases that all appeared in the studied corpus only once. However, their importance lies in their

\begin{tabular}{l|c} 
& Frequency \\
\hline $\begin{array}{l}\text { go as far as your ambition } \\
\text { will take you }\end{array}$ & 1 \\
\hline $\begin{array}{l}\text { get you moving in the right } \\
\text { direction }\end{array}$ & 1 \\
\hline $\begin{array}{l}\text { extraordinary milestones } \\
\text { of success }\end{array}$ & 1 \\
\hline $\begin{array}{l}\text { best opportunities are still } \\
\text { before us }\end{array}$ & 1 \\
\hline \begin{tabular}{l} 
the sky's the limit \\
\hline
\end{tabular} & 1 \\
\hline
\end{tabular}

\section{Orientational Metaphor}

Table 6

Globalism

Table 7

Orientational metaphor creativity and imagery. 


\section{Conclusion}

\section{References}

With the exception of the last example - the sky's the limit - which is of the UP IS GOOD type, all of these phrases belong to the FRONT IS GOOD - BACK IS BAD and also FORESEEABLE FUTURE EVENTS ARE AHEAD types of orientational metaphor. Furthermore, the positive imagery is enhanced by the fact that all of these phrases are not only orientational metaphors but also conceptual metaphors of the type CAREER IS A JOURNEY. The combination of these three metaphors makes the applicant visualize his/her career as a path he or she is walking on, directing towards a better tomorrow and leaving everything bad behind.

The analysis focused on the language of recruitment advertising, in particular on company profiles that make part of job ads, and proved that using positively evaluative lexis in this type of texts was fairly common and that certain tendencies could be observed. The analysis showed that four main strategies were employed: 1) positive ATTITUDE, 2) positive ATTITUDE in combination with orientational metaphor, 3) purr words, and 4) orientational metaphors. The first category includes words that belong to three subsystems - AFFECT, JUDGEMENT and APPRECIATION, and include in particular expressions putting stress on working and doing things together (e.g., team, family, collaborate), on being experts and professionals (e.g., help, talent, expert), on improvement and innovation (e.g., grow, innovative, development) and on being better than others (e.g., leader, best, top).

The positive attitudinal meaning of some of these words is enhanced by the fact that the words are also orientational metaphors; this is the case of the words lead, grow, build and top. The first is the most frequent evaluative word identified in the corpus and the orientational metaphor that supports its positive perception is based on the pattern FRONT IS GOOD, thus implying that whoever is the leader is better and deserves to be followed or joined in the leading position. The other three expressions are orientational metaphors of the type UP IS GOOD. The purr words that have been identified in the corpus are all positive vague abstract words, such as vision, mission, goal, dream or challenge. It is rarely explained what the visions, missions or goals of the companies are, allowing each reader to understand it in his or her own way. Last but not least, the orientational metaphor WHOLE IS GOOD is manifested in the words used to imply that a company is a global player.

It is worth noting that the tendencies and strategies that were detailed in this article are seen by many as a major shortcoming of today's corporate language and should, therefore, be eradicated. Indeed, the extreme frequency of some words, phrases and syntactic patterns can sometimes be counterproductive, as it makes the company profiles of different companies almost identical and it is almost impossible to distinguish one from another. Emphasis is put on the evocation of positive feelings to the detriment of meaningful content, resulting in language reminiscent of Orwell's novel Nineteen Eighty-Four and his concepts of newspeak and duckspeak. The only way out of this common practice seems to be breaking away from employing the above-described expressions that have now become a sort of a cliché and introducing more creative language in combination with more emphasis put on the relevant content of the message that is being conveyed. This approach might make one's text stand out among those of their competitors.

1. Bednarek, M., 2009. Corpora and Discourse: A Three-Pronged Approach to Analyzing Linguistic Data. In: Selected Proceedings of the 2008 HCSNet Workshop on Designing the Australian National Corpus, (eds.) Haugh, M.,
Burridge, K., Mulder, J., Peters, P. Somerville. MA: Cascadilla Proceedings Project, pp. 19-24.

2. Bolinger, D.,1980. Language, the Loaded Weapon: The Use and Abuse of Language Today. New York: Longman. 
3. Gingell, J., 2015. George Orwell, Human Resources and the English Language. In: The Guardian. Retrieved from: https:// www.theguardian.com/media/mind-yourlanguage/2015/jul/03/george-orwellhuman-resources-and-the-english-language [Accessed 13 January 2018].

4. Halliday, M. A. K., \& Matthiessen, C. M. I. M., 2004. An Introduction to Functional Grammar. London: Hodder Education.

5. Halliday, M. A. K., 2007. Language as Social Semiotic: Towards a General Sociolinguistic Theory. In: Language and Society, (ed.) Webster, J. London: Continuum, pp. 169-202.

6. Hart, C., 2014. Discourse, Grammar and Ideology: Functional and Cognitive Perspectives. New York: Bloomsbury.

7. Hayakawa, S. I., 1949. Language in Thought and Action. New York: Harcourt, Brace and Co.

8. Hunston, S., \& Thompson, G., 1999. Evaluation in Text. Authorial Stance and the Construction of Discourse. New York: Oxford University Press.

9. Hunston, S., 2007. Semantic Prosody Revisited. In: International Journal of Corpus Linguistics, 12(2). John Benjamins Publishing Company, pp. 249-268.

10. Klein, J., 2014. Grundlagen der Politolinguistik. Berlin: Frank \& Timme.

11. Kövecses, Z., 2010. Metaphor: A Practical Introduction. Oxford: Oxford University Press.

12. Łącka-Badura, J., 2015. Recruitment Advertising as an Instrument of Employer Branding. Newcastle: Cambridge Scholars Publishing.

13. Lakoff, G., \& Johnson, M., 1980. Metaphors We Live By. Chicago: The University of Chicago Press.

14. Leech, G., 1983. Principles of Pragmatics. London: Longman.

15. Leech, G., 1990. Semantics: The Study of Meaning. London: Penguin Books.
16. Lutz, W., 1990. Doublespeak: From "Revenue Enhancement" to "Terminal Living": How Government, Business, Advertisers, and Others Use Language to Deceive You. New York: HarperPerennial.

17. Lutz, W., 1996. The New Doublespeak: Why No One Knows What Anyone's Saying Anymore. New York: HarperCollins Publishers.

18. Martin, J. R., 1999. Beyond Exchange: APPRAISAL Systems in English. In: Evaluation in Text. Authorial Stance and the Construction of Discourse, (eds.) Hunston, S., Thompson, G. New York: Oxford University Press.

19. Martin, J. R., \& White, P. R. R., 2005. The Language of Evaluation: Appraisal in English. New York: Palgrave Macmillan.

20. Niehr, T., 2014. Einführung in die Politolinguistik. Göttingen: UTB.

21. Orwell, G., 1946. Politics and the English Language. In: Horizon, 13(76), pp. 252-265. Rpt. in What Orwell Didn't Know: Propaganda and the New Face of American Politics, (ed.) Szántó, A. New York: PublicAffairs, pp. 205-222.

22. Oxford Dictionary of Synonyms and Antonyms, 2007. Oxford: Oxford University Press.

23. Rafaeli, A., 2001. Employee Organizational Relationships in Employment Ads. In: Work Motivation in the Context of a Globalising Economy, (eds.) Erez, M., Kleinbeck, U., Thierry, H. Mahawah, NJ: Lawrence Erlbaum Associates, pp. 247-260.

24. Sinclair, J., 2004. The Search for Units of Meaning. In: Trust the Text. Language, Corpus and Discourse, (ed.) Sinclair, J. London/New York: Routledge, pp. 24-48.

25. Stewart, D., 2010. Semantic Prosody: A Critical Evaluation. New York: Routledge.

26. White, P. R. R., 2015. The Language of Attitude, Arguability and Interpersonal Positioning. The Appraisal Website. Retrieved from: http://www.languageofevaluation. info/appraisal/ [Accessed 26 January 2018].

Pavel Reich. „Didžiuojamès, kad esame pirmaujanti, visuotinai pripažinta ir pasaulinę jtaką turinti įmonè": teigiamai konotuota idarbinimo reklamos leksika

Teigiamas imonès pristatymas tapo esmine darbo skelbimų dalimi, kuri padeda darbdaviams pritraukti potencialiu kandidatu i laisvas darbo vietas. Šiame straipsnyje daugiausia dèmesio skiriama ivairiai pozityviai vertinančiai leksikai, kuri randama ¿moniu profiliuose, 
skelbiamuose ¿darbinimo svetainèje Monster.com. Vertinamieji arba papildomi žodžiai gali būti apibrež̌iami kaip žodžiai, teigiamai arba neigiamai vertinantys tikrovę, taip sukeliant žmonems teigiamą ar neigiamą požiūri i tam tikrą subjektą, šiuo atveju i potencialu darbdavi.

Kiekybine ir kokybinè analizè yra grindžiama triju krypčių metodu, t. y. atskirų tekstu, mažos apimties tekstų rinkinio ir didelès apimties tekstų rinkinio rankinės analizės deriniu. Ji pirmiausia paremta vertinimo teorija, skiriančia daugiausia dėmesio žodynui, kuris vartojamas požiūriui išreikšti. Tačiau ši analizè parodè, kad darbdavių, bandančiu pritraukti darbuotojus, ¡̇tikinamosios priemonès yra gana sudètingos, todèl paaiškèjo, kad būtina atsižvelgti i kitas teorijas, būtent konceptualiosios metaforos ir vadinamuju praleistų žodžiu koncepciją, t. y. žodžių, kurių konceptuali reikšmè yra pagrįsta teigiamomis konotacijomis. Ši politinès lingvistikos koncepcija neseniai buvo sukurta Vokietijoje, o jos konceptai vadinami šūkiais, tačiau, kaip parodè analizè, šią teoriją galima sèkmingai iš politinio diskurso perkelti i korporacini, taip pat ir i idarbinimo diskursą.

\section{About the Pavel Reich \\ Author PhD, Assistant Professor, Department of Language and Cultural Studies, Faculty of Regional Development and International Studies, Mendel University in Brno, Czech Republic}

\section{Academic interests}

English for specific purposes, evaluation in language, lexical semantics, doublespeak, corpus linguistics

\section{Address}

Department of Language and Cultural Studies, Faculty of Regional Development and International Studies, Mendel University in Brno, Generála Píky 7, 61300 Brno, Czech Republic

\section{E-mail}

reich.pa@gmail.com 